\title{
The Role Of Fathers In Children's Development Of Emotional Quotient And Intelligence In Gbi Medan Plaza
}

\author{
Sry Haru Sinamo \\ \{celie_sinamo@yahoo.com\} \\ Postgraduate Program, Pelita Kebenaran School of Theology
}

\begin{abstract}
In a family each person has a role. The father figure is needed by his wife along with his children to influence the feelings and attitudes for the wife to raise the children. Model attitudes are positive behaviors of adults such as parents such as fathers to their children, in families helping to develop the potential of children's emotional abilities. What is crucially important to see in children is emotional development and intelligence. The role of the father can be a factor in developing emotional quotient and intelligence in children. Emotions and intelligence need stimulation from an early age in order for children to grow and have emotional skills and intelligence in the stages of development. Motivation is the ability to give enthusiasm to someone to do something good and beneficial; children need such things in order to form their emotions and intelligence. This research uses a qualitative descriptive approach. Interviews and observation were carried out with participants, namely ten fathers and their children. The results show that fathers have taken a big role in emotional quotient and intelligence in children. Although parenting orientation is a sense of responsibility between father and mother.
\end{abstract}

Keywords: Children Development, emotional quotient, intelligence

\section{Introduction}

The family consists of father, mother and child. Each has a different role. Parents play an important role in the success of educating children. The role of a father is needed in building emotional intelligence and intelligence of children. If a father gives full love to children, the child will feel happy and feel comfortable when close to his father and vice versa if a father does not give attention and affection to his child, then the child will feel sad and feel uncomfortable when with his father. Early childhood is a child who desperately needs a father figure because each father and mother have roles that cannot be replaced by anyone.

Regarding parenting, the father's role is no less important than mother's. Starting from the development of children from birth to adulthood. Children growing up with fathers involved in parenting have social and academic lives that tend to be better, than those who are distant or not having good relations with their father. "We found that children in their fostering patterns involving fathers tend to have fewer problems." So said Maureen Black, $\mathrm{PhD}$, researcher and professor of pediatrics at the University of Maryland School of Medicine. Specifically, Black's research shows, these children have better speech skills, and fewer behavioral problems, when in their upbringing involves a father figure. As is known by the role of father can be a factor in developing emotional intelligence and intelligence in children.

Emotions and intelligence need to be stimulated from an early age so that children can grow and have emotional skills and intelligence in accordance with the stages of development. 
a person should provide a motivation for his child because motivation is the ability to give enthusiasm to oneself to do something good and beneficial, early childhood needs such things in the formation of emotions and intelligence.

\subsection{Parenting Parents}

In a family, parents are demanded to possess managerial skills or technical skills. Therefore in the family they must be able to capture the hearts of children, in order to develop harmony between children with technical expertise to foster children, and provide examples of role models for children so that children can imitate how daily behavior. In the family there are three types of parenting given by parents to their children:

1. Parenting parents who give coercion to their children or what is called authoritarian.

2. Parenting parents who invite children to collaborate in something is called democratic.

3. Parenting is given to parents by providing children with monitoring their own activities called permissive.

\subsection{Father's Role}

The effect of having the father's role during early childhood is very influential for the long term because a father has an important role in raising and watching over his child not only his mother. Father's role will influence the development of children's social skills, cognitive development, and emotional development.

Types of father's role in the pattern of early childhood care:

a. A father is also responsible for the development of discipline towards children. Children will imitate his father through interactions that are carried out because basically discipline is not only related to violence, punishment.

b. The role of a father will also provide a sense of security to his child so that his child feels safe and comfortable. A father will understand where the advantages and disadvantages of his child so that the child's father provides protection for his child.

\subsection{Emotional Intelligence}

According to Santrock, (2011) Emotions are feelings that occur during interactions. The child develops from birth to adults. In all stages of development there will be emotional influences on children (Qodariah \& Pebriani, 2016). Emotions are divided into, smile, shy, crying, laughing, sad, angry.

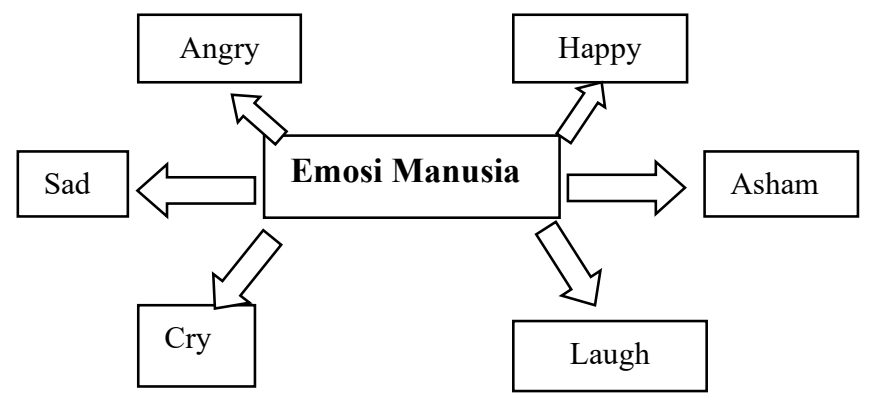

Fig.1 Various human emotions manusia. 
According to Goleman (1995) there are several productive benefits of emotions, including:

a. More responsible.

b. More able to focus on the task at hand and pay attention (concentration).

c. Less impulsive.

d. More self-control.

e. Increased work performance.

Responsible

Less impulsive

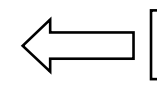

Benefits of emotions
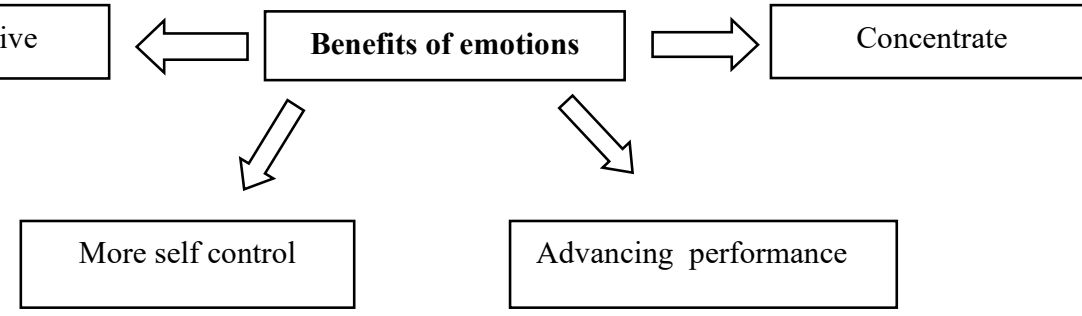

Advancing performance

Fig. 2. Benefits of Emotions

\subsection{Intelligence}

Frequently people fail not because of poor intelligence, but a tendency of low emotional quotient. Daniel Goleman in Emotional Intelligence says that emotional quotient is the most important part among other intelligences. He also explains that humans have two brains, two minds and two different types of intelligence, namely rational intelligence and emotional intelligence. Our success in life is determined by both, not just IQ, but emotional intelligence plays a role. Indeed, intellect cannot work well without emotional intelligence.

Gardner (1993: 24) suggests that humans have seven kinds of intelligence, namely musical intelligence, mathematical logic, bodily kinesthetic intelligence, linguistic intelligence, spatial intelligence, interpersonal intelligence, and intrapersonal intelligence.

\section{Research Method}

This research is qualitative research where data is obtained through a qualitative descriptive approach. The choice of this model is because it is more flexible and centered on the subject of research.

\subsection{Population}

The population of this study are fathers and children who are in one of the branches at GBI Medan Plaza. The method taken is random sampling, which is the withdrawal of random and simple samples taken as many as 10 people consisting of father and child. 


\subsection{Data Collection}

Data is collected by interviewing fathers and children at the HDTI branch of one of the branches in the GBI Medan Plaza). Interviews are meetings of two people to exchange information through question and answer so that meaning can be constructed in a particular topic. In this case the researcher asks directly to fathers and children about their role in caring for/accompanying children.

Data is collected by interviewing fathers and children at the HDTI branch of one of the branches in the GBI Medan Plaza). Interviews are meetings of two people to exchange information through question and answer so that meaning can be constructed in a particular topic. In this case the researcher asks directly to fathers and children about their role in caring for/ accompanying children.

\section{Result and Discussion}

Based on the results of analysis at the GBI Medan Plaza Branch of HDTI, the results/functions of the father have a major impact on the emotional quotient and intelligence of children. It can be concluded that the father has a lot of influence on the development of children. In this regard, the family environment, school and society must provide conditions for the children in order for them to develop their intelligence. From results it can be seen that the role of father's assistance is very influential as seen from the achievements of the children obtained each semester. There is a concrete increase in achievement and association can be noticed to have been largely impacted by parents' behavior.

Table 1. Impact of Father's Role on Children in Daily Life

\begin{tabular}{|c|c|c|c|c|c|c|c|c|}
\hline $\begin{array}{l}\text { Child's } \\
\text { name }\end{array}$ & $\begin{array}{c}\text { Watch } \\
\text { TV }\end{array}$ & Holiday & $\begin{array}{c}\text { Playing } \\
\text { gadget }\end{array}$ & Studying & Playing & Worship & $\begin{array}{c}\text { Reading } \\
\text { Bible }\end{array}$ & $\begin{array}{c}\text { Academic } \\
\text { Performan } \\
\text { ce (class } \\
\text { rank) }\end{array}$ \\
\hline $\begin{array}{l}\text { Kaleb } \\
(10 \\
\text { years } \\
\text { old })\end{array}$ & 2hours & Active & $\begin{array}{c}\text { Sat-Sun } \\
\text { (5hours/hr) }\end{array}$ & Active & Active & Active & Active & $\mathrm{R}=2$ \\
\hline $\begin{array}{l}\text { Baim ( } 8 \\
\text { ears } \\
\text { old) }\end{array}$ & Active & Active & $\begin{array}{c}\text { Sat-Sun } \\
\text { (2hours/hr) }\end{array}$ & Active & Active & Active & Active & $\mathrm{R}=3 \mathrm{big}$ \\
\hline $\begin{array}{l}\text { Samuel } \\
\text { (7 years } \\
\text { old) }\end{array}$ & Active & Active & - & Active & Active & Active & Active & $\mathrm{R}=3$ \\
\hline $\begin{array}{l}\text { Darren } \\
(13 \\
\text { years } \\
\text { old })\end{array}$ & $\begin{array}{c}\text { Active } \\
\text { (Sat- } \\
\text { Sun) }\end{array}$ & Active & Active & Active & Active & Active & Active & $\mathrm{R}=3$ \\
\hline $\begin{array}{l}\text { Valerie } \\
(11 \\
\text { years } \\
\text { old })\end{array}$ & $\begin{array}{l}\text { Sat-Sun } \\
\text { (6hours) }\end{array}$ & Active & $\begin{array}{l}\text { Sat-Sun } \\
\text { (back from } \\
\text { school) }\end{array}$ & Active & Active & Active & Active & $\mathrm{R}=10$ \\
\hline
\end{tabular}




\section{Conclusion}

Based on the results of these studies it is concluded that the role of the father will influence the development of social skills, cognitive development, and emotional children. These findings can be input for the next researcher or for parents.

\section{References}

[1] Drs. Mardalis, Metodologi Penelitian,suatu pendekatan proposal (Jakarta:Bumi Karsa;20079) cet 9, hal 26

[2] Daniel Goleman, Kecerdasan Emosional, Terj. dari Emotional Intellegence oleh T. Hermaya, (Jakarta: Gramedia Pustaka Utama: 1996) cet. I, hal. 38

[3] Nabilla Tashandra "Pahami, Arti Penting Ayah yang Mengasuh Anak... ",

[4] https://lifestyle.kompas.com/read/2018/11/12/145718220/pahami-arti-penting-ayah-yangmengasuh-anak.

[5] Santrock, J. W. (2011). Masa Perkembangan Anak. Jakarta: Salemba Humanika.

[6] Tia novela, "Dampak peran ayah terhadap perkembangan emosional anak usia dini"

[7] Wirawan, Evaluasi :Teori, Model, Metodologi, Standar, Aplikasi dan Profesi (Jakarta:RajaGrafindo Persada,2016) 211

[8] https://media.iyaa.com/article/2016/06/Ada-6-Tipe-Pola-Asuh-Orangtua-kepada-Anak3453883.html

[9] http://myblokoke.blogspot.com/2015/03/teori-kecerdasan-berganda-dari-howard.html 